\title{
Analysis of the Relationship between Ego Identity Status and Personality Traits and General Self-Efficacy with Structural Equation Modeling
}

\author{
Mehmet Behzat Turan ${ }^{1} \&$ Kenan Koç ${ }^{1}$ \\ ${ }^{1}$ Erciyes University, Faculty of Sport Sciences, Kayseri, Turkey \\ Correspondence: Mehmet Behzat Turan, Erciyes University, Faculty of Sport Sciences, 38039, Kayseri, Turkey. \\ Tel: 90-542-824-0066. E-mail: behzatturan@erciyes.edu.tr
}

Received: October 20, 2018

Accepted: November 9, 2018 Online Published: November 28, 2018

doi:10.5539/hes.v8n4p190

URL: https://doi.org/10.5539/hes.v8n4p190

\begin{abstract}
In this study, it is aimed to investigate the partial mediating effect of ego identity status and personality traits on general self-efficacy levels of physical education and sports teacher candidates. To do that, a model showing possible relationships between these variables was established and this model was tested by using structural equation modeling. The sample of the study consisted of 578 students in the freshmen, sophomore, junior, and senior years in the Physical Education Sports Teaching Departments of universities Erciyes, Mehmet Akif, Dumlupinar, and Ahi Evran. The Socio-Demographic Information Form created by the researchers, General Self-Efficacy Scale adapted to Turkish by Aypay (2010), Ego Identity Status Scale adapted by Oskay (1998), and Eysenck Personality Questionnaire adapted to Turkish by Karanc1 et al. (2007) were used as the data collection tools. SPSS 22 program and Structural Equation Modeling/AMOS/Path Diagram program were used for data analysis. Firstly, the measurement models were tested and the proposed measurement model proved to be able to use to test the structural model. The structural model proposed based on the validated measurement models were then tested and verified. The fit indices of the model established in the study were found to be good and the coefficients obtained were found to be statistically significant. According to the results obtained about the structural model, it was found that there was a significant relationship between the general self-efficacy with ego identity status and personality traits, and that the ego identity status and personality traits predict the general self-efficacy in an advanced level.

As a result, it is thought that the general self-efficacy levels of the students will increase with the positive development of ego identity status and personality traits, and this increase will enable the students to increase their academic achievement and self-confidence, as well as will make them more active in the society.
\end{abstract}

Keywords: physical education and sports, general self-efficacy, ego identity status, personality traits

\section{Introduction}

Nowadays, universities are no longer the places where uniform information are transferred, and they have evolved into living systems that try to provide the equipment that will be needed by future generations in every aspect. In addition to the transfer of technical information to students, individual-specific services began to become widespread. In terms of providing individual development, it has become very important to determine what influences the psychology and mind worlds of people and how their personalities are shaped. At this point, it is necessary to determine which variables are related to raising the individuals who have high general self-efficacy and deciding what kind of training will be given. As a result of this kind of scientific determinations made, it can be ensured that higher quality educational environments are created and schools can be more effective in the process of gaining general self-efficacy. Individuals with high self-efficacy are known to be more successful in educational settings.

The concept of general self-efficacy includes elements such as planning an action, being aware of the necessary skills and bringing them together, the level of motivation as a result of the preliminary judgment of the gains to be achieved with the difficulties. Thus, general self-sufficiency does not correspond to being talented, but to trust one's own resources (Karademir, 2010; Yıldırım \& İlhan, 2010). However, self-efficacy perception is also stated to be effective in many areas such as cognitive, behavioral, affective, and selective processes (Karahan \& Balat, 
2011), as well as physical performance, pain resistance, mental health, coping with fears, emotional disorders, academic achievement, social skills, career identification (Albayrak, Okçin, \& Gerçeklioğlu, 2013). Self-efficacy is important in measuring the potential of prospective teachers because this will affect success. Considering the related areas, it is possible to think that general self-efficacy is primarily related to identity status and personality traits.

One of the generally accepted approaches to identity status is Marcia's (1966) theory of ego identity status, which is categorized under four main headings as follows:

Successful identity means internal investment following a discovery process and is associated with consideration of potential living options (Berzonsky, 2004; Zimmer-Gembeck, \& Petherick, 2006). Individuals with successful identity status have solved the basic conflict of adolescence and have achieved identity acquisition and are in harmony with themselves (Marcia, 1966; Kroger, 2004).

Suspended identity implies the situation taking active consideration of alternatives related to identity areas, but not making a strong internal investment. This status is associated with openness and curiosity (Luyck, Goossens, $\&$ Soenens, 2006) and also on anxiety, depression, and low ego (Schwartz et al., 2009).

Encumbered identity means internal investment after a weak discovery process. This identity is associated with rigidity, closed-mindedness, and authoritarianism, as well as high ego (Kroger \& Marcia, 2011).

Individuals with dispersiveness identity status do not make an internal investment in the choice of profession, religious belief, and political opinion, but they still do temporary research. The individuals in question did not experience an identity crisis related to these areas where they could be directed, did not conduct reconsideration, and did not evaluate the options (Kroger, 1989).

The task of building identity requires a review, research, and decision-making process. The discovery size involves the adolescent trying to recognize the options and look for answers. The internal investment dimension is a meaningful choice that directs behavior. In this process of acquiring this identity, which Marcia emphasized as a lifelong process, a transition between statuses is possible due to some psychosocial changes in the life of the individual, and it is emphasized that the identity structure is not a static but dynamic structure (Marcia, 2002a).

Considering the ideology and interpersonal fields when performing identity tasks, while occupation, work, spouse selection, and faith are related, it is observed that there are links between social life and identity formation, hence at this very point, it is thought that general self-efficacy may be closely related to identity status.

On the other hand, even though personality theorists have identified personality differently with touching upon distinct points in line with their own schools, it is also possible to define the personality generally as the whole of "individual, consistent, and structured features that distinguish the individual from others" (İnanç \& Yerlikaya, 2012).

Eysenck initially evaluated personality in two broad factors as neuroticism and extraversion, and then in a four-factor structure including neuroticism, extraversion, psychoticism, and lie. The extraversion dimension represents sociality and impulsivity, the neuroticism dimension represents emotional consistency and hyper responsiveness, while the psychoticism dimension represents coldness.

In the light of these explanations, the purpose of the current study is to determine the relationship and if so the level of that relationship between ego identity status and personality traits with general self-efficacy.

\section{Material and Method}

\subsection{Research Model}

This research is in a relational screening model. This screening model can be defined as "the research models aiming to determine the existence and/or degree of existence between two and more variables" (Karasar, 2007).

\subsection{Data Collection Tools}

During the application of the questionnaires to be applied to the students in the research, besides the researchers, the instructors working at the university have created a healthy evaluation process for the candidates by making necessary explanations in a wide time without rushing. In addition, suitable materials and environmental conditions were provided for the candidates to fill the forms in a comfortable situation. Data collection tools used in the research are General Self-Efficacy (GSE) Scale, Eysenck Personality Questionnaire (EPQ), Ego Identity Status (EIS) Scale, and Socio-Demographic Information Form (SDIF). 


\subsection{Creating Volunteer Groups}

The research is conducted through working groups. The workgroup of 640 volunteer students randomly selected among 1360 candidates from the Physical Education Sports Teaching Departments of universities Erciyes, Mehmet Akif, Dumlupinar, and Ahi Evran, in their freshmen, sophomore, junior, and senior years during the 2017-2018 academic year constitute the sample of the research.

\subsection{Socio-Demographic Information Form}

In order to define the demographic characteristics of the students by the researcher, the form consisting of five questions including Gender, Age, University, Class, and Grade Point Average (Gpa) have been created.

\subsection{General Self-Efficacy Scale}

The Turkish version of GSE scale, which was developed by Schwarzer and Jerusalem (2005) and adapted to more than 25 languages, was created by Aypay (2010) through a study on 693 students from three different universities. In the adaptation study, the scale form was applied to 711 students in the fall semester of the 2005-2006 academic year based on voluntary participation. The validity and reliability studies of the scale were carried out using data of 693 which were accepted as valid. As a result of AFA, two factors were explained which accounted for $47 \%$ of the total variance and whose eigenvalues were greater than 1 . Prior to rotation, all scale items took the weight from the first basic component in a positive direction over .47. The eigenvalue of the first basic component is 3.66. It was seen that the common variances of the two factors identified with respect to the items ranged from .33 to .63 except for one item. In order to examine the criterion validity of the GSE scale, Türküm's (2002) Coping with Stress Scale (CSS) and Rosenberg's Self-Esteem Scale (RSE) were applied. While there was no significant relationship between the whole GES scale and CSS, there was a positive, moderately significant relationship between the scores obtained from the GSE scale and CSS scores $(r=.40, p<.001)$. There was a positive and moderate significant relationship between scale scores of GSE and RSE $(r=.38, p<.001)$.

\subsection{Extended Objective Measure of Ego Identity Status}

To determine the identity status of the students, the Extended Objective Measure of Ego Identity Status (EOM-EIS) developed by Marcia (1966), prepared by Bennion and Adams (1986), and adapted into Turkish by Oskay (1998) was utilized. This sixty-four-item scale differentiates 4 different identity states: successful identity, suspended identity, encumbered identity, and dispersiveness. The scale was a 6-point Likert type and the participants were asked to indicate their validity for each item. In the adaptation study, the internal consistency coefficients of the scale ranged between .57 and .84 and the test-retest reliability ranged from .72 to .81 . In this study, internal consistency coefficients of dispersiveness, encumbered, suspended, and successful identity subscales were determined as $.72, .89, .80$, and .74 , respectively.

\subsection{Eysenck Personality Questionnaire}

In order to measure the personality traits of the students, the Revised-Abbreviated Form of Eysenck Personality Questionnaire (EPQR-A) developed by Francis, Brown , and Philipchalk (1992) and adopted into Turkish by Karanc1 et al. (2007) was applied. EPQR-A consists of 24 items and 4 subscales that are neuroticism, extraversion, psychoticism, and lie subscales (Francis, Brown, \& Philipchalk, 1992).

The internal consistency coefficient of the scale was found to be as $.78, .65, .42$, and .64 , and test-retest consistency as .84, .82, .69, and .69 for extroversion, neuroticism, psychoticism, and lye dimensions, respectively (Karanc1, Dirik, \& Yorulmaz, 2007). In this questionnaire where each factor is evaluated with 6 items, the participant is asked to respond to the 24 questions in the format Yes (1) or No (0). The score for each personality trait varies from 0 to 6 .

\subsection{Analysis of Data}

In this research, firstly all participants were informed about the purpose of the study. Data were analyzed by using SPSS 20 and AMOS programs. In the analysis of the data, the data set was examined in terms of bad value, outlier, normality, and multiple correlations. In this process, it was observed that there were no mistakenly input false data. Confirmatory factor analysis (CFA) was performed by using the AMOS program. Many confirmatory fit indices are used in this analysis. If the chi-square/degree of the freedom ratio fit index is smaller than 5 , it means moderate fit and if smaller than 2.5, perfect fit (Çokluk, Şekercioğlu, \& Büyüköztürk, 2010). The Root Mean Square Error of Approximation (RMSEA) fit index being smaller than .06 means the model is perfectly fit, and if less than .10, the fit level is acceptable. Normed Fit Index (NFI) and Comparative Fit Index (CFI) values equal to or greater than .95 indicate a good-fit model (Thomson, 2004). Again, Goodness of Fit Index (GFI) and Adjusted Goodness of Fit Index (AGFI) values equal to or greater than .90 is accepted as proof of a good fit of 
the model. The fact that the Root Mean Square Residuals (RMR) fit index being less than .05 is also a sign of good compliance (Çokluk, Şekercioğlu, \& Büyüköztürk, 2010).

Table 1. The Demographic Profile of The Participants

\begin{tabular}{llll}
\hline Variances & Groups & N & \% \\
\hline Gender & Male & 348 & 60,2 \\
& Female & 230 & 39,8 \\
\hline Age & $18-21$ & 205 & 35,5 \\
& $22-25$ & 320 & 55,4 \\
& $26-29$ & 53 & 9,2 \\
\hline University & Erciyes & 164 & 28,4 \\
& Mehmet Akif Ersoy & 140 & 24,2 \\
& Dumlupinar & 135 & 23,4 \\
& Ahi Evran & 139 & 24,0 \\
\hline Class & 1 & 144 & 24,9 \\
& 2 & 141 & 24,4 \\
& 3 & 143 & 24,7 \\
& 4 & 150 & 26,0 \\
\hline Gpa & $1.25-1.99$ & 50 & 8,7 \\
& $2.00-2.99$ & 310 & 53,6 \\
& $3.00-4.00$ & 218 & 37,7 \\
\hline
\end{tabular}

When Table 1 is examined, it is seen that $60.2 \%$ of the participants are male and $39.8 \%$ are female. In terms of the age variable, the proportion of $18-21$ years old is $35.5 \%, 22-25$ years old is $55.5 \%$, and $26-29$ years old is 9.2\%. When the university variable is examined, Erciyes University constituted 28.4\%, Mehmet Akif Ersoy University 24.2\%, Dumlupinar University 23.5-4\%, and Ahi Evran 24\%. In terms of their study year, the rate of the first class (freshmen) was $24.9 \%$, the second class (sophomore) was $24.4 \%$, the third class (junior) was $24.7 \%$, and the fourth grade (senior) was $26 \%$. With regards to Gpa, the ratio of those between $1.25-1.99$ is $8.7 \%$, between $2.00-2.99$ is $53.6 \%$, and between $3.00-4.00$ is $37.7 \%$.

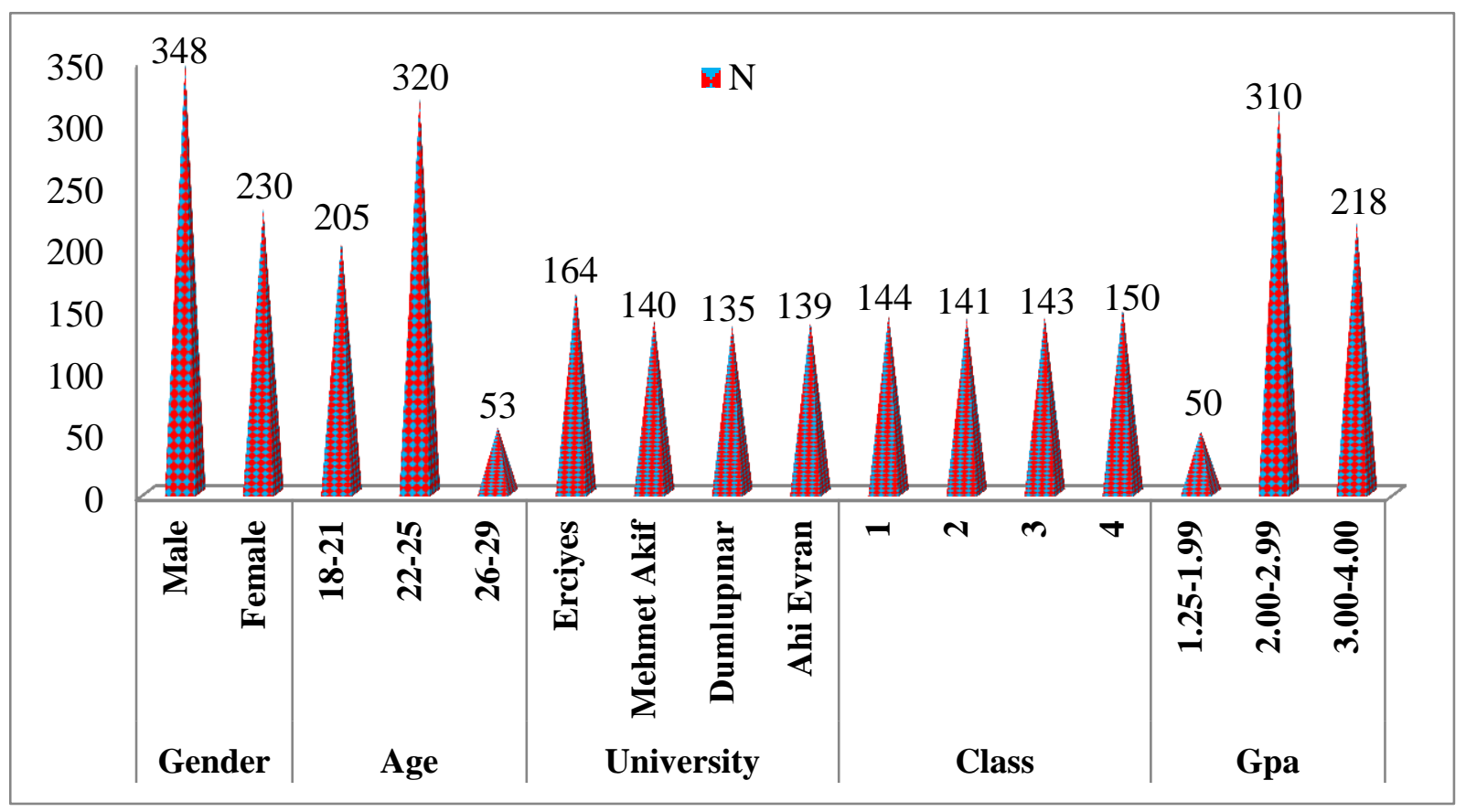

Figure 1. The Demographic profile of the participants 


\section{Findings}

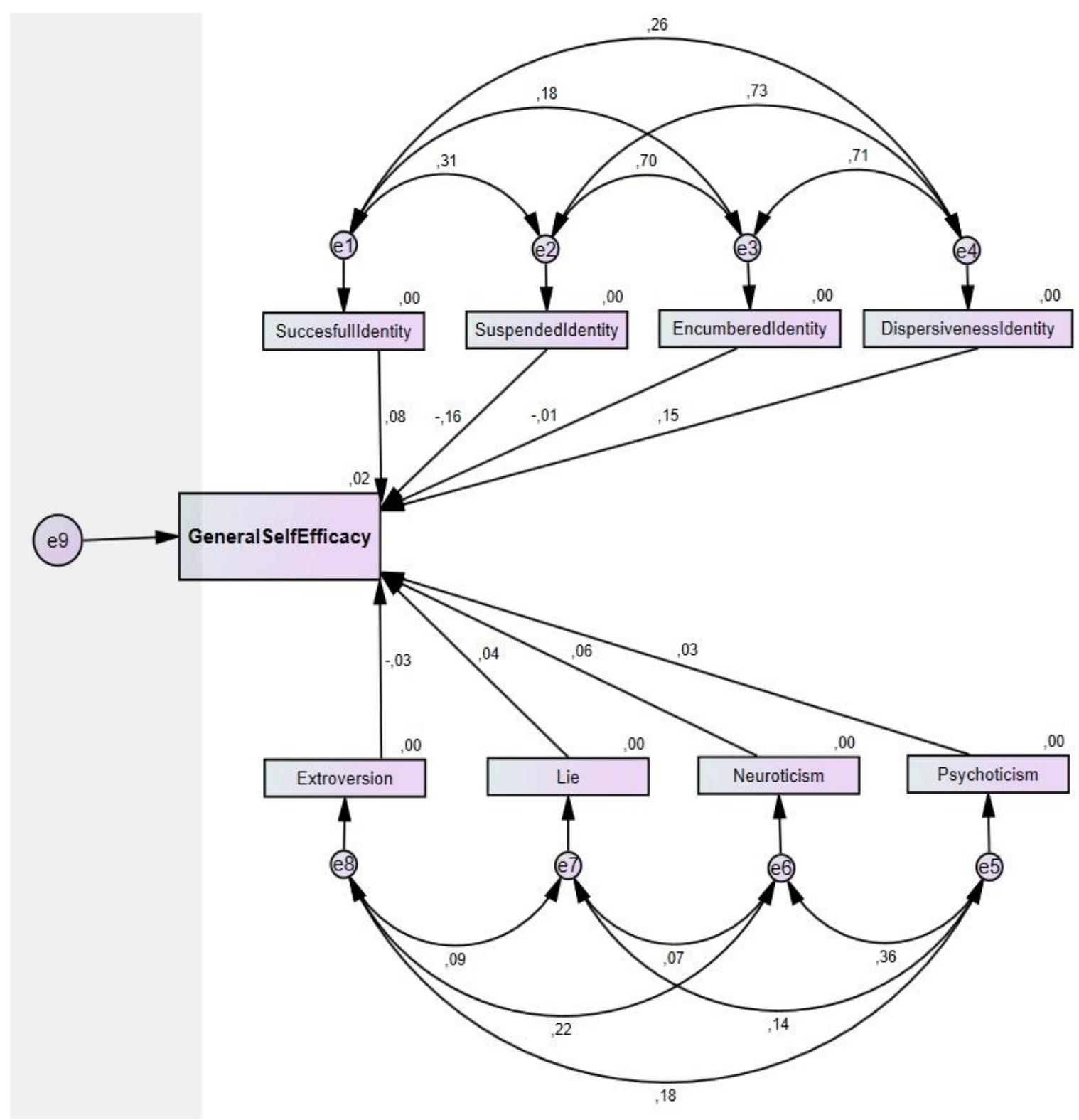

Figure 2. The Hypothesized Model Consisting: Personal Qualities, Ego Identity Status, and General Self-Efficacy

Table 2. Personal Qualities, Ego Identity Status and General Self-Efficacy Model Fit Indexes

\begin{tabular}{lllllllll}
\hline Model & $\mathbf{X}^{\mathbf{2}}$ & $\mathbf{d f}$ & $\mathbf{X}^{\mathbf{2}} / \mathbf{d f}$ & $\mathbf{N F I}$ & $\mathbf{T L I}$ & $\mathbf{C F I}$ & GFI & RMSEA \\
\hline & 21.524 & 16 & 1.354 & .951 & .969 & .986 & .994 & .024 \\
\hline
\end{tabular}

When the fit indices for confirmatory factor analysis were examined, it was found that the ratio of chi-square to the degree of freedom ratio has an excellent value $(21.524 / 16=1.354)$ below 2.5. When the other fit indices were examined they are found as following: $\mathrm{RMSEA}=.024, \mathrm{GFI}=.994, \mathrm{NFI}=.951, \mathrm{CFI}=.986$. The fact that NFI and GFI values calculated as above 0.90 show an acceptable level of fit; the CFI value higher than 0.95 , indicates excellent fit. RMSEA value found between $0.05 \leq$ RMSEA $\leq .0 .10$ indicates an acceptable level of fit. When the good-fit indexes obtained as a result of confirmatory factor analysis are examined, it is seen that it is a good-fit-model. 
Table 3. Correlation Coefficients of the Scores between General Self-Efficacy, Ego Identity Statutes and Personal Traits

\begin{tabular}{|c|c|c|c|c|c|c|c|c|c|c|}
\hline & & 1 & 2 & 3 & 4 & 5 & 6 & 7 & 8 & 9 \\
\hline \multirow{3}{*}{$\begin{array}{l}\text { General } \\
\text { Efficacy }^{1}\end{array}$} & $\mathrm{r}$ & 1 & & & & & & & & \\
\hline & $\mathrm{p}$ & & & & & & & & & \\
\hline & $\mathrm{N}$ & 578 & & & & & & & & \\
\hline \multirow{3}{*}{$\begin{array}{l}\text { Successful } \\
\text { Identity }^{2}\end{array}$} & $\mathrm{r}$ & $.591 * *$ & 1 & & & & & & & \\
\hline & $\mathrm{p}$ & .000 & & & & & & & & \\
\hline & $\mathrm{N}$ & 578 & 578 & & & & & & & \\
\hline \multirow{3}{*}{$\begin{array}{l}\text { Suspended } \\
\text { Identity }^{3}\end{array}$} & $\mathrm{r}$ & $-.030 *$ & $.308^{* *}$ & 1 & & & & & & \\
\hline & $\mathrm{p}$ & .047 & .000 & & & & & & & \\
\hline & $\mathrm{N}$ & 578 & 578 & 578 & & & & & & \\
\hline \multirow{3}{*}{$\begin{array}{l}\text { Encumbered } \\
\text { identity }^{4}\end{array}$} & $\mathrm{r}$ & $.075^{*}$ & $.187^{* *}$ & $.700^{* *}$ & 1 & & & & & \\
\hline & $\mathrm{p}$ & .038 & .000 & .000 & & & & & & \\
\hline & $\mathrm{N}$ & 578 & 578 & 578 & 578 & & & & & \\
\hline \multirow{3}{*}{$\begin{array}{l}\text { Dispersiveness } \\
\text { Identity }^{5}\end{array}$} & $\mathrm{r}$ & .045 & $.249^{* *}$ & $.728^{* *}$ & $.720^{* *}$ & 1 & & & & \\
\hline & $\mathrm{p}$ & .276 & .000 & .000 & .000 & & & & & \\
\hline & $\mathrm{N}$ & 578 & 578 & 578 & 578 & 578 & & & & \\
\hline \multirow[t]{3}{*}{ Extroversion $^{6}$} & $\mathrm{r}$ & $-.040 *$ & $-.016^{*}$ & $-.104^{*}$ & -.045 & $-.085^{*}$ & 1 & & & \\
\hline & $\mathrm{p}$ & .044 & .048 & .013 & .285 & .040 & & & & \\
\hline & $\mathrm{N}$ & 578 & 578 & 578 & 578 & 578 & 578 & & & \\
\hline \multirow[t]{3}{*}{$\mathrm{Lie}^{7}$} & $\mathrm{r}$ & -.190 & .015 & .002 & $-.022 *$ & $-.024 *$ & .079 & 1 & & \\
\hline & $\mathrm{p}$ & .227 & .723 & .958 & .045 & .044 & .056 & & & \\
\hline & $\mathrm{N}$ & 578 & 578 & 578 & 578 & 578 & 578 & 578 & & \\
\hline \multirow[t]{3}{*}{ Neuroticism $^{8}$} & $\mathrm{r}$ & $-.052 *$ & $.030^{*}$ & -.013 & $-.066^{*}$ & -.065 & $.220^{* *}$ & .067 & 1 & \\
\hline & $\mathrm{p}$ & .041 & .047 & .747 & .031 & .121 & .000 & .107 & & \\
\hline & $\mathrm{N}$ & 578 & 578 & 578 & 578 & 578 & 578 & 578 & 578 & \\
\hline \multirow[t]{3}{*}{ Psychoticism? } & $\mathrm{r}$ & $-.037 *$ & .007 & .043 & .041 & .057 & $.162^{* * *}$ & $.119^{* *}$ & $.350^{* *}$ & 1 \\
\hline & $\mathrm{p}$ & .016 & .870 & .300 & .328 & .169 & .000 & .004 & .000 & \\
\hline & $\mathrm{N}$ & 578 & 578 & 578 & 578 & 578 & 578 & 578 & 578 & 578 \\
\hline
\end{tabular}

When Table 3 is examined, General Self Efficacy has high correlation with Successful Identity $(r=.591, p<0.01)$ in positive direction, low correlation with Suspended Identity $(r=-.30, p<0.05)$ in negative direction, and low correlation with Encumbered Identity $(r=.075, \mathrm{p}<0.05)$ in positive direction, but no significant relationship was found between GSE and Dispersiveness Identity $(r=.045, \mathrm{p}>0.05)$.

Furthermore, it is observed that General Self Efficacy has low correlation with Extroversion sub-dimension $(\mathrm{r}=$ $-.40, \mathrm{p}<0.05)$ in negative direction, low correlation with Neuroticism $(\mathrm{r}=-.052, \mathrm{p}<0.05)$ in negative direction, and low correlation with Psychoticism $(r=-.037, \mathrm{p}<0.05)$ in negative direction. No significant relationships with Lie sub-dimension $(r=-.190, p>0.05)$ was detected.

On the other hand, Successful Identity has low correlation with Extroversion sub-dimension $(r=-.16, p<0.05)$ in negative direction, low correlation with Neuroticism $(\mathrm{r}=.030, \mathrm{p}<0.05)$ in positive direction. Yet no significant relationships with Lie $(r=.015, \mathrm{p}>0.05)$ and Psychoticism $(r=.007, \mathrm{p}>0.05)$ sub-dimensions was detected.

Suspended Identity only has low correlation with Extroversion sub-dimension $(r=-.104, p<0.05)$ in negative direction, while it has no meaningful relationship with Neuroticism $(r=-.013, p>0.05)$, Lie $(r=.002, p>0.05)$, and Psychoticism ( $r=.043, \mathrm{p}>0.05)$ sub-dimensions.

Meanwhile, Encumbered Identity has low correlation with Lie sub-dimension $(r=-.122, p<0.05)$ in negative direction, low correlation with Neuroticism $(r=-.066, \mathrm{p}<0.05)$ in negative direction. However, no significant relationships with Extroversion $(r=-.045, \mathrm{p}>0.05)$ and Psychoticism $(\mathrm{r}=.041, \mathrm{p}>0.05)$ sub-dimensions was detected. Finally, Dispersiveness Identity has low correlation with Extroversion sub-dimension $(r=-.85, p<0.05)$ in positive direction, low correlation with Lie $(r=-.24, p<0.05)$ in negative direction, while no significant relationships with Neuroticism $(r=-.065, \mathrm{p}>0.05)$ and Psychoticism $(r=-.065, \mathrm{p}>0.05)$ sub-dimensions was detected. 
Tablo 4. Variances: (Group Number 1- Default Model)

\begin{tabular}{cccccl}
\hline & Estimate & S.E & C.R. & P & \multicolumn{1}{c}{ Label } \\
\hline e1 & .613 & .033 & 18.385 & $0,000^{* *}$ & Successful Identity \\
\hline e2 & .838 & .043 & 19.550 & $0,000^{* *}$ & Suspended Identity \\
\hline e3 & 1.325 & .063 & 20.903 & $0,000^{* *}$ & Encumbered Identity \\
\hline e4 & .811 & .046 & 17.793 & $0,000^{* *}$ & Dispersiveness Identity \\
\hline e5 & 1.341 & .076 & 17.707 & $0,000^{* *}$ & Psychoticism \\
\hline e6 & 1.969 & .097 & 20.324 & $0,000^{* *}$ & Neuroticism \\
\hline e7 & .919 & .055 & 16.600 & $0,000^{* *}$ & Lie \\
\hline e8 & 1.353 & .074 & 18.173 & $0,000^{* *}$ & Extroversion \\
\hline e9 & 21.246 & 1.269 & 16.739 & $0,000^{* *}$ & General Self-Efficacy \\
\hline
\end{tabular}

When Table 4 examined, parameter estimates for investigation show that all parameters are significantly different from zero. The absolute value of $\mathrm{z}$ calculated for all parameters that are critical ratio is greater than 1.96.

Table 5. Structural Equation and R2 Value Obtained with AMOS

\begin{tabular}{ll}
\hline Structural Equation & R2 \\
\hline GSE $=-.028 * \mathrm{e} 1+.043 * \mathrm{e} 2+195 * \mathrm{e} 3+.114 * \mathrm{e} 4+.801 * \mathrm{e} 5+-.053 * \mathrm{e} 6+-.797 * \mathrm{e} 7+.452 * \mathrm{e} 8$ & $\mathbf{0 . 7 2 7}$ \\
\hline
\end{tabular}

From Table 5 it is seen, personality traits and ego identity status predicted the general self-efficacy level as $72.7 \%$ in the structural equation modeling.

\section{Discussion and Conclusion}

One of the multivariate statistical analysis methods, the structural equation model technique, tries to model the causality relationship structure between two or more sets of variables. In this study, it is aimed to explain the relationship between identity status and personality traits with general self-efficacy of students studying in sports sciences faculties of various universities by using Structural Equation Modeling technique. When the results of the study are examined, it is seen that the model is compatible with the general self-efficacy and identity status and personality traits. At the same time, it was determined that general self-efficacy predicts ego identity status and personality traits by $72 \%$.

When the correlation coefficients are examined, it is seen that the general self-efficacy has a high degree correlation with successful identity and a low degree correlation with the suspended identity both in the positive direction. Individuals with successful identity status have solved the basic conflict of adolescence and have achieved identity acquisition and are in harmony with themselves (Marcia, 1966; Kroger, 2004). For this reason, it is thought that the prospective teachers who have reached the university age, made the choice of profession and made their decisions about the future reached the successful identity status will have the general self-efficacy that will require self-sufficiency, be organized and stand on their own feet. Individuals with suspended identity are those who have anxiety, depression, and low self-esteem (Schwartz et al., 2009). However, the efforts of individuals are parallel to the strength of their self-efficacy and the likelihood of the selected activity is successfully carried out also relies on it (Bandura, 1997; Kenny, 2012). The individuals with high self-efficacy perception who came to the age of university may be led to successful identity status from suspended identity through high-level education, the existence of applied courses, mostly the adoption of a lifestyle which is independent of the family.

On the other hand, when the correlation results of general self-efficacy and personality traits were examined, a negative correlation with extroversion was detected. While the extraversion represents sociality and impulsivity, those who receive high scores in this dimension are defined as people who prefer to be with individuals rather than being alone (Karanc1, 2007). The extrovert type considers objects with values. It organizes its actions according to the objects, rather than the subjects. They are more interested in the world outside themselves. They easily and quickly adapt to the common rules and values of the environment in which they live. In such cases, the individual reflects the feelings and thoughts they do not recognize to the objects in their environment when they become conscious of the feelings and thoughts in the depths of their inner world, whereas it is the faith of the individual with high self-efficacy help to combat with the situations that arise and to coordinate the skills to change that (Binay, 2016). Teachers with high self-efficacy are considered to be individuals who solve their own problems and they are considered to have low extraversion characteristics because they give importance to 
personalities.

Moreover, low-level positive relationships with neuroticism and psychoticism sub-dimensions were determined. People with high neuroticism experience more frequent stresses against daily events than those with low levels. Although there are many kinds of negative emotions such as sadness, anger, anxiety, and guilt, research has shown that people who tend to one of these negative emotions often tend to have others (Burger, 2006). The sub-dimension of psychoticism refers to more extraordinary personality traits such as being cold, distant, aggressive, insecure, emotionless, bizarre, guilt, lack of empathy, insensitive to other people (Karanc1, 2007). On the other hand, general self-sufficiency concerns almost all aspects of human life such as how people think pessimistic or optimistic about something, how and to what extent they motivate themselves, and what life choices they make (Pajares, 2002). General self-efficacy refers to a person's sufficiency in coping with stressful and challenging life events in general (Scholz \& Schwarzer, 2005). It is also defined as the general confidence of a person to new situations one face in many areas in which it is difficult to master or they are not used to overcome (Scholz, Gutierrez-Dona, Sud \& Schwarzer, 2002). When the definitions of neuroticism and psychoticism are compared with the general self-efficacy definitions, it is seen that they are opposite to one another and the findings obtained are supported by the literature.

Consequently, it is thought that the general self-efficacy levels of the students will increase by providing positive development of ego identity status and personality traits. With this increase, it is thought that students' academic success and self-confidence will increase, and thus, they will be more active in society.

\section{Suggestions}

- Activities related to the development of personality can be included in the curriculum together with discipline-specific knowledge.

- The sample of this research is limited to the prospective physical education teachers at the university level and it is difficult to generalize the findings for other branches. It can be said that a similar study on other disciplines and determining the problems in those disciplines and developing solutions for them would contribute to the relevant literature.

- To improve self-efficacy and to contribute to personality traits and identity tasks; the use of techniques to develop positive attitudes such as pair works, group work, role-playing, simulation, and problem-solving can be suggested.

- Teachers positively affect the personality development of students by taking individual differences into consideration. The courses can be conducted where the differences are taken into account to motivate the students and providing diversity with using visual and audio materials.

- The environment of the course should be reassuring and comfortable for students. To help students develop positive attitudes toward their self-efficacy and reduce their anxiety, relevant activities can be organized in the courses. When evaluating the outcomes of the course, the self-efficacy of the students should be determined according to their levels. In this context, attention should also be paid to these issues when preparing education programs.

\section{References}

Albayrak, O. F., \& Gerçeklioğlu, G. (2013) Öğrencilerin Öz-Etkililik-Yeterlilik Algılları ve Sosyal Destek Düzeylerinin İncelenmesi. Gümüşhane Üniversitesi Sağllk Bilimleri Dergisi, 2(1), 40-51.

Aypay, A. (2010). Genel Öz Yeterlik Ölçeği’nin (GÖYÖ) Türkçe’ye Uyarlama Çalışması (s.113-131). İnönü Üniversitesi Eğitim Fakültesi Dergisi, 11(2).

Bandura, A. (1997). Self-efficacy: The Exercise of Control. W.H. Freeman and Company, New York, U.S.A.

Berzonsky, M. D. (2004). Identity Style, Parental Authority, and Identity Commitment. Journal of Youth and Adolescence, 33(3), 213-220. https://doi.org/10.1023/B:JOYO.0000025320.89778.29

Binay, Ş., \& Yiğit, R. (2016). Relationship between Adolescents' Health Promoting Lifestyle Behaviours and Self-Efficacy. J Pediatr Res., 3(4), 180-186. https://doi.org/10.4274/jpr.18894

Çokluk, Ö., Şekercioğlu, G., \& Büyüköztürk, Ş. (2010). Sosyal Bilimler İ̧̧in Çok Değişkenli İstatistik. Pegem Yayınları, Ankara

Francis, L. J., Brown, L. B., \& Philipchalk, R. (1992). The Development of An Abbreviated Form of The Revised Eysenck Personality Questionnaire (EPQR-A): İts Use among Students in England, Canada, The USA and Australia. Pers Individ Dif., 13, 443-449. https://doi.org/10.1016/0191-8869(92)90073-X

İnanç, B. Y., \& Yerlikaya, E. E. (2012). Kişilik Kuramları, 6. Baskı, Ankara: Pegem Akademi Yayınları. 
Karademir, N. (2010). Coğrafya Öğretmenlerinin Alanlarına İlişkin Öz-Yeterlik Algılarının İncelenmesi. E-Journal of New World Sciences Academy, 5(4), 2034-2048.

Karahan, Ş., \& Balat, G. U. (2011). Özel Eğitim Okullarında Çalışan Eğitimcilerin Öz-Yeterlik Algılarının ve Tükenmişlik Düzeylerinin İncelenmesi. Pamukkale Üniversitesi Eğitim Fakültesi Dergisi, 29(1), 1-14

Karanc1, N., Dirik, G., \& Yorulmaz, O. (2007). Eysenck Kişilik Anketi-Gözden Geçirilmiş Kısaltılmış Formu'nun (EKA-GGK) Türkiye'de Geçerlik ve Güvenilirlik Çalışması. Türk Psikiyatri Dergisi, 18(3), 255.

Karasar, N. (2007). Bilimsel Araştırma Yöntemi (17.baskı), Ankara, Nobel Yayın Dağıtım, 49-53

Kenny, R. F., Park, C L., Van Neste-Kenny, J. M. C., Burton, P., \& Qayyum, A. (2012) Using Self-Efficacy To Assess The Readiness of Nursing Educators and Students for Mobile Learning. IRRODL, 13(3), 277-296. https://doi.org/10.19173/irrodl.v13i3.1221

Kroger, J. (1989). Identity in Adolescence. The Balance between Self and Other. London: Routledge.

Kroger, J. (2004). Identity in Adolescence: The Balance Between Self and Other. Adolescence and Society Series, Routledge, 36-51.

Kroger, J., \& Marcia, J. E. (2011). The İdentity Statuses: Origins, Meanings, and Interpretations. In S. J. Schwartz, K. Luyckx, Ve V. L. Vignoles (Eds.), Handbook of İdentity Theory and Research, Springer, New York. 31-54. https://doi.org/10.1007/978-1-4419-7988-9_2

Luyckx, K., Goossens, L., \& Soenens, B. (2006). A Developmental Contextual Perspective on İdentity Construction in Emerging Adulthood: Change Dynamics in Commitment Formation and Commitment Evaluation. Developmental Psychology, 42, 366-380. https://doi.org/10.1037/0012-1649.42.2.366

Marcia, J. E. (1966). Development Andvalidation of Ego-İdentitystatus. Journal of Personality and Socialpsychology, 3, 551-558. https://doi.org/10.1037/h0023281

Marcia, J. E. (2002). Adolescence, Identity, and the Bernardone Family. Identity: An International Journal of Theory and Research, 2(3), 199-209. https://doi.org/10.1207/S1532706XID0203_01

Oskay, G. (1998). Genişletilmiş Obejktif Ego Kimlik Statüsü Ölceği'nin [Extended Objective Measure of Ego Identity Status)-EOM-EIS' in Türkçe'ye Uyarlanması. Türk Psikolojik Danışma Ve Rehberlik Dergisi, 2(9), $17-24$.

Pajares, F. (2002) Overview of Social Cognitive Theory and Self-Efficacy. Retrieved from http://www.des.emory.edu/mfp/eff.html adresinden elde edildi.

Raykov, T., \& Marcoulides, G. A. (2000). A First Course in Structural Equation Modeling. New Jersey: Lawrence Erlbaum Associates

Scholz, U., Gutierrez- Dona, B., Sud, S., \& Schwarzer, R. (2002). Is General Self Efficacy A Universal Construct? European Journal of Psychological Assessment, 18(3), 242-251. https://doi.org/10.1027//1015-5759.18.3.242

Schwartz, S. J., Mason, C. A., Pantin, H., Wang, W., Brown, C., Campo, A. E., \& Szapocznik, J. (2009). Relationships of Social Context and İdentitiy to Problem Behaviour among High-Risk Hispanic Adolescents. Youth and Society, 40, 541-570. https://doi.org/10.1177/0044118X08327506

Schwarzer, R., \& Jerusalem, M. (1995). Generalized Self-Efficacy scale. In J. Weinman, S. Wright, \& M. Johnston, Measures In Health Psychology: A User's Portfolio. Causal and Control Beliefs (S.). Windsor, Uk: Nfer-Nelson. 35-37

Thomson, B. (2004). Exploratory and Confirmatory Factor Analysis. Washington: APA.

Türküm, A. S. (2002). Stresle Başa Çıkma Ölçeğinin Geliştirilmesi: Geçerlik ve Güvenilirlik Çalışmaları (S.25-34) Türk Psikolojik Danışma ve Rehberlik Dergisi, 2, 18.

Yıldırım, F., \& İlhan, İ. Ö. (2010) Genel Öz Yeterlilik Ölçeği Türkçe Formunun Geçerlilik ve Güvenilirlik Çalışması. Türk Psikiyatri Dergisi, 21(4), 301-308.

Zimmer-Gembeck, M. J., \& Petherick, J. (2006). Intimacy Dating Goals and Relationship Satisfaction During Adolescence and Emerging Adulthood: Identity Formation, Age and Sex As Moderators. International Journal of Behavioral Development, 30(2), 167-175. https://doi.org/10.1177/0165025406063636 


\section{Copyrights}

Copyright for this article is retained by the author(s), with first publication rights granted to the journal.

This is an open-access article distributed under the terms and conditions of the Creative Commons Attribution license (http://creativecommons.org/licenses/by/4.0/). 